\title{
PELATIHAN PEMANFAATAN GOOGLE FORM PADA APARAT DAN PERANGKAT DESA NEGARA SAKA KABUPATEN PESAWARAN DALAM RANGKA PENINGKATAN PROGRAM KERJA DESA
}

\author{
Niar Azriya, Novalia, Defiana Sari, Guntana \\ Fakultas Ekonomi Universitas Sang Bumi Ruwa Jurai \\ niarazriya@gmail.com
}

\begin{abstract}
Abstrak
Data merupakan keterangan objektif tentang suatu fakta baik dalam bentuk kualitatif maupun gambar visual yang diperoleh melalui observasi langsung maupun dari yang sudah terkumpul. Basis data dan informasi yang valid dan terukur maka proses perencanaan pembangunan yang baik dan komprehensif akan menjadi titik penting dalam keberhasilan pembangunan desa. Desa Negara Saka yang terletak di Kabupaten Pesawaran belum memilikinya data desa terbaru sehingga hal tersebut menyebabkan terhambatnya kpala desa dalam menentukan program kerja yang sesuai. Dengan memanfaatkan fasilitas internet untuk memudahkan aparat desa dalam pengumpulan data yang cepat dan akurat, sehingga memudahkan pihak kepala desa dalam menentukan program untuk perkembangan dan pembangunan desa yang sesuai. Oleh karena itu, pada pengadian ini, Fakultas Ekonomi melakukan kegiatn pegabdian dengan mengenalkan dan memanfaatkan fasilitas Google Form dalam pengumpulan data.
\end{abstract}

Kata Kunci: data desa, google form, internet

Abstract

Data is objective information about a fact both in the form of qualitative and visual images obtained through direct observation or from what has been collected. Valid and measurable database and information, a good and comprehensive development planning process will be an important point in the success of village development. Negara Saka Village, which is located in Pesawaran Regency, does not have the latest village data, so this causes obstruction of the village head in determining the appropriate work program. By utilizing internet facilities to facilitate village officials in fast and accurate data collection, making it easier for the village head to determine programs for appropriate village development and development. Therefore, at this event, the Faculty of Economics conducted service activities by introducing and utilizing Google Form facilities in data collection.

Keywords: village data, google form, internet,

\section{PENDAHULUAN}

Menurut Undang-Undang No. 25 Tahun 2004 tentang Sistem Perencanaan Pembangunan Nasional pada pasal 31: Data adalah keterangan objektif tentang suatu fakta baik dalam bentuk kuantitatif, kualitatif maupun gambar visual yang diperoleh baik melalui observasi langsung maupun dari yang sudah terkumpul dalam bentuk cetakan atau perangkat penyimpanan lainnya. Artinya, data yang diperoleh harus merupakan fakta bukan hasil manipulasi ataupun rekayasa. Dengan memiliki basis data dan informasi yang valid dan terukur, maka proses perencanaan pembangunan yang baik dan komprehensif akan menjadi titik penting untuk berhasilnya pembangunan. 
Seminar Nasional Penelitian dan Pengabdian kepada Masyarakat Universitas Sang Bumi Ruwa Jurai Tahun 2020

Pembangunan desa di Indonesia saat ini mendapatkan perhatian khusus dari pemerintah. Bentuk keseriusan pemerintah dalam pembangunan desa salah satunya melalui dana desa yang diberikan bagi setiap desa. Dalam pengelolaan dana desa membutuhkan berbagai data terkait kependudukan, kelembagaan, dan karakteristik spesifik desa dalam pengelolaan dana guna menunjang proses perencanaan pembangunan desa. Data desa digunakan dalam proses analisis dan penyusunan program dalam merencanakan pembangunan desa agar pembangunan tersebut dapat diterima dan sesuai dengan kebutuhan masyarakat.

Dalam proses perencanaan pembangunan desa data desa berperan sangat penting, sehingga pemerintah desa harus berusaha untuk menyediakan data terkait karakteristik spesifik desanya. Hal tersebut dapat terwujud dalam bentuk profil desa. Berdasarkan Peraturan Menteri Dalam Negeri Nomor 12 Tahun 2007 tentang pedoman penyusunan dan pendayagunaan data profil desa kelurahan, profil desa dan kelurahan adalah gambaran menyeluruh tentang karakter desa dan kelurahan yang meliputi data dasar keluarga, potensi sumber daya alam, sumber daya manusia, kelembagaan, prasarana dan sarana serta perkembangan kemajuan dan permasalahan yang dihadapi desa dan kelurahan.

Seiring perkembangan teknologi yang begitu pesat, sistem informasi berbasis komputer sangat berpengaruh dalam dunia kerja, begitu juga informasi berbasis web dimanfaatkan sebagai sarana peningkatan informasi. Pemanfaatan tersebut mempermudah suatu pekerjaan seperti halnya pengolahan data lebih cepat, keputusan yang akan diambil lebih cepat, menghemat waktu dan biaya. Selain itu, sistem informasi yang berbasis web juga dapat menjadi sarana promosi yang efisien dan sumber informasi yang dapat diakses oleh pengguna internet yang semakin luas, pemanfaatan sistem informasi berbasis komputer sangat membantu dalam kegiatan sehari-hari.

Negara Saka merupakan salah satu desa yang berada di Kecamatan Negeri Katon Kabupaten Pesawaran. Negara Saka berjarak sekitar 16 km dari Kantor Kecamatan Negeri Katon. Profil Desa Negara Saka saat ini masih menggunakan data tahun 2018. Data desa perlu dilakukan pembaharuan, sehingga kepala desa tidak keliru dalam menentukan arah perkembangan desa dan dapat mendeteksi permasalahan yang menghambat laju perkembangan masyarakat. Aparat desa selaku pemberi layanan kepada masyarakat perlu meningkatkan kualitas layanannya. Prinsip dalam penyelenggaraan pelayanan publik diantaranya adalah akurasi, dan kemudahan akses. Kemudahan akses menjadi hal yang penting sehingga memudahkan masyarakat dan perangkat desa dalam memperoleh informasi.

Google Form atau google formulir merupakan salah satu alat yang berfungsi bagi penggunanya dalam merencanakan acara, mengirim survey, atau mengumpulkan informasi yang mudah dengan cara yang efisien. Google Form dapat dimanfaatkan sebagai media berbasis online untuk kebutuhan penggunanya khususnya dalam pembuatan kuesioner online, sehingga pengolahan data lebih terjamin dan terintegrasi dengan baik karena dengan memanfaatkan komputer sebagai pengolahan data elektronik.

Data desa yang valid menjadi sangat penting untuk kemajuan desa tersebut. Jika data yang dimiliki pihak desa tidak valid maka, aparat desa akan kesulitan dalam pembuatan anggaran yang dibutuhkan dalam pengembangan desa. Dilihat dari segi kesehatan jika jumlah data balita yang dimiliki oleh desa tidak sesuai dengan keadaan yang sesungguhnya maka dapat menyebabkan terjadinya kurangnya jumlah vaksin yang harus diterima oleh balita yang ada di desa tersebut. Program kerja yang akan dibuat oleh pihak desa juga menjadi tidak terarah pada saat data desa tidak valid, hal ini terjadi di desa Negara Saka. Kebanyakan warga desa Negara Saka merupakan 
lulusan pesantren dan pada saat mereka akan melamar pekerjaan ataupun melanjutkan pendidikan dibutuhkan penyetaraan pendidikan yaitu paket C. Pihak desa mengalami kesulitan dalam mendata berapa jumlah warga desa yang memang membutuhkan paket C. Jika data yang dimiliki oleh desa tersebut valid maka akan memudahkan desa dalam menentukan program yang akan dilakukan bagi perkembangan pendidikan warga desanya. Data desa yang tidak valid menyebabkan ketidak sesuaian dalam penentuan program kerja desa.

\section{METODE}

Metode pelatihan yang digunakan dalam pelatihan ini adalah ceramah dan latihan. Jadwal kegiatan pengabdian kepada masyarakat ada pada Tabel 1.

Tabel. 1 Jadwal Kegiatan

\begin{tabular}{|c|c|c|c|c|c|}
\hline \multirow[t]{2}{*}{ No } & \multirow[t]{2}{*}{ Kegiatan } & \multicolumn{3}{|c|}{ Bulan } & \multirow[t]{2}{*}{ Pelaksana } \\
\hline & & Juli & Agustus & September & \\
\hline 1 & Survey & $\sqrt{ }$ & $\sqrt{ }$ & & Ketua Team \\
\hline & Pendahuluan & & & & Pengabdian \\
\hline 2 & Koordinasi dengan & $\sqrt{ }$ & $\sqrt{ }$ & & Ketua Team \\
\hline & $\begin{array}{l}\text { Kepala Desa } \\
\text { Negara Saka }\end{array}$ & & & & Pengabdian \\
\hline 3 & Identifikasi & $\sqrt{ }$ & $\sqrt{ }$ & & Team \\
\hline 4 & $\begin{array}{l}\text { masalan } \\
\text { Penyusunan }\end{array}$ & $\sqrt{ }$ & $\sqrt{ }$ & & $\begin{array}{c}\text { Pengabdian } \\
\text { Team }\end{array}$ \\
\hline & Proposal PKM & & & & Pengabdian \\
\hline 4 & $\begin{array}{l}\text { Penyusunan materi } \\
\text { pelatihan }\end{array}$ & $\sqrt{ }$ & $\sqrt{ }$ & & $\begin{array}{c}\text { Team } \\
\text { Pengabdian }\end{array}$ \\
\hline 5 & $\begin{array}{l}\text { Pembuatan modul } \\
\text { pelatihan }\end{array}$ & $\sqrt{ }$ & $\sqrt{ }$ & & $\begin{array}{c}\text { Team } \\
\text { Pengabdian }\end{array}$ \\
\hline 6 & $\begin{array}{l}\text { Sosialisasi dan } \\
\text { pelatihan }\end{array}$ & & $\sqrt{ }$ & & $\begin{array}{c}\text { Team } \\
\text { Pengabdian }\end{array}$ \\
\hline 7 & $\begin{array}{l}\text { Penyusunan } \\
\text { Laporan PKM }\end{array}$ & & & $\sqrt{ }$ & $\begin{array}{c}\text { Team } \\
\text { Pengabdian }\end{array}$ \\
\hline
\end{tabular}

\section{Peserta}

Peserta pelatihan adalah aparat desa terdiri dari seluruh pegawai di balai desa dan perangkat desa di Negara Saka, Kecamatan Negeri Katon Kabupaten Pesawaran.

\section{Metode Pelaksanaan}

Untuk mencapai tujuan yang telah dirumuskan sebelumnya, pelaksanaan pengabdian kepada masyarkat ini dilakukan dalam beberapa langkah yang melibatkan metode penelitian lapangan berupa:

1. Indentifikasi masalah yang dilakukan sebagai langkah awal untuk merumuskan apa saja yang akan dijadikan bahan sebagai materi pelatihan dalam kegiatan pengabdian ini 
Seminar Nasional Penelitian dan Pengabdian kepada Masyarakat Universitas Sang Bumi Ruwa Jurai Tahun 2020

2. Melakukan survey lapangan dengan diskusi dan wawancara bersama Kepala Desa Negara Saka, Kabupaten Pesawaran, Bapak Saironi untuk analisis dan mengidentifikasi kebutuhan perangkat desa.

3. Penelitian pustaka untuk acuan materi yang digunakan selama kegiatan pengabdian ini

4. Pembuatan modul pelatihan penggunaan Google Form untuk kuesioner yang

\section{HASIL DAN PEMBAHASAN}

Pelakasanaan pengabdian masyarakat dilakukan dalam dua tahap kegiatan yaitu survei dan pelaksanaan kegiatan Dalam perencanaan kegiatan ini, awalnya ketua tim pengabdian melakukan survey ke lokasi rencan pengabdian dengan membangun komunikasi bersama dengan Kepala Desa Negara Saka, Bapak Saironi. Dalam diskusi bersama dnegan bapak kepala desa, diperlukan adanya kegiatan pelatihan penggunaan Google Form untuk aparat dan perangkat Desa Negara Saka dalam upaya pemanfaatan teknologi informasi untuk memudahkan pekerjaan aparat desa. Kemudian tim pengabdian Fakultas Ekonomi meancang suatu kegiatan pengabdian dengan judul "Pelatihan Pemanfaatan Google Form Pada Aparat Dan Perangkat Desa Negara Saka Kabupaten Pesawaran Dalam Rangka Peningkatan Program Kerja Desa".

Pelaksanaan kegiatan pada tanggal 14 Maret 2020. Diadakan di Balai Desa Negara Saka, Kecamatan Negeri Katon, Kebupaten Pesawaran. Acara dimulai dan dibuka pada pukul 09.00 oleh Kepala Desa Negara Saka, Bapak Saironi. Kemudian dilanjutkan dengan penyampaian materi pendahuluan dan pengenalan antar muka Google Form yang disampaikan oleh Ibu Novalia, S.Pd., M.Si. Penyampaian materi menggunakan slide dan di sesi akhir kegiatan, parat dan perangkat desa langsung hands-on menggunakan laptop dan smartphone masing-masing untuk membuat contoh kuesioner menggunakan Google Form. Semua anggota tim baik dosen maupun mahasiswa ikut membantu mendampingi perangkat dan aparat desa dalam melakukan hands-on membuat contoh kuesioner berdasarkan materi yang dipaparkan oleh narasumber. Selama kegiatan berlangsung tim pengabdi dosen dan mahasiswa selaku tenaga lapangan membantu aparat dan perangkat desa yang belum memahami atau yang mengalami kesulitan dalam membuat contoh kuesioner dengan baik.

Dari hasil pelakasanaan kegiatan ini output yang diperoleh adalah meningkatkannya pengetahuan dan keahlian aparat dan perangkat Desa Negara Saka dalam memanfaatkan penggunaan teknologi informasi, salah satu layanan dari platform Google untuk membuat kuesioner online. Ilmu baru ini diharapkan juga mempermudah pekerjaan aparat desa dalam memperoleh umpan balik dalam pembuatan kuesioner. Lebih lanjut di akhir kegiatan pengabdian ini, Bapak Saironi menyampaikan terimakasih atas kegiatan pengabdian kepada masyarakat dari Fakultas Ekonomi Universitas Sang Bumi Ruwa Jurai di Desa Negara Saka, Kecamatan Negeri Katon Kabupaten Pesawaran dan beliau juga menyampaiakn penemimaannya untuk kegiatan lain dari dosen Universitas Sang Bumi Ruwa Jurai yang memiliki dampak positif bagi peningkatan pengetahuan dan kemampuan aparat desa di Desa Negara Saka. 
Seminar Nasional Penelitian dan Pengabdian kepada Masyarakat Universitas Sang Bumi Ruwa Jurai Tahun 2020

Tabel 3. Justifikasi Pemakaian Anggaran Pelakasnaan Pengabdian

\begin{tabular}{|c|c|c|c|c|c|}
\hline No & Keterangan & Satuan & $\begin{array}{c}\text { Biaya } \\
\text { Satuan } \\
\text { (Rp) }\end{array}$ & Jumlah & $\begin{array}{l}\text { Biaya } \\
(\mathbf{R p})\end{array}$ \\
\hline & \multicolumn{5}{|l|}{ Survey } \\
\hline 1 & Bahan Bakar Survey & Liter & 9.200 & 20 & 184.000 \\
\hline \multirow[t]{2}{*}{2} & Makan Siang Survey & Kotak & 20.000 & 4 & 80.000 \\
\hline & Pelaksanaan & & & & \\
\hline 3 & $\begin{array}{l}\text { Bahan Bakar Hari } \\
\text { Pelaksanaan }\end{array}$ & Liter & 9.200 & 20 & 184.000 \\
\hline 4 & $\begin{array}{l}\text { Makan Siang Hari } \\
\text { Pelaksanaan }\end{array}$ & Kotak & 20.000 & 25 & 500.000 \\
\hline 5 & Snack Hari Pelaksanaan & Kotak & 15.000 & 25 & 375.000 \\
\hline 6 & Pengadaan Proposal & Eksamplar & 25.000 & 5 & 125.000 \\
\hline 7 & Pengadaan Laporan Akhir & Eksamplar & 35.000 & 5 & 175.000 \\
\hline 8 & $\begin{array}{l}\text { ATK dan Fotocopy Modul } \\
\text { Pelatihan }\end{array}$ & Eksamplar & 40.000 & 20 & 800.000 \\
\hline 9 & Spanduk ukuran $3 \times 1$ meter & Buah & 50.000 & 2 & 100.000 \\
\hline \multirow[t]{2}{*}{10} & Pulsa internet & Buah & 100.000 & 4 & 400.000 \\
\hline & TO' & & & & 2.923.000 \\
\hline
\end{tabular}

\section{KESIMPULAN}

Data merupakan keterangan objektif tentang suatu fakta baik dalam bentuk kualitatif maupun gambar visual yang diperoleh melalui observasi langsung maupun dari yang sudah terkumpul. Basis data dan informasi yang valid dan terukur maka proses perencanaan pembangunan yang baik dan komprehensif akan menjadi titik penting dalam keberhasilan pembangunan desa. Desa Negara Saka. Output yang diperoleh dari pelaksanaan pengabdian ini adalah meningkatkannya pengetahuan dan keahlian aparat dan perangkat Desa Negara Saka dalam memanfaatkan penggunaan teknologi informasi.

\section{DAFTAR PUSTAKA}

Febriadi, Bayu dan Nurliana Nasution. 2017. Sosialisasi dan Pelatihan Aplikasi Google Form sebagai Kuisioner Online Untuk Meningkatkan Kualitas Palayanan. Jurnal Inovtek PolbengSeri Informatika, Vol.2, No. 1, Juni 2017

Mardiana, Tia dan Arif W. Purnanto. 2017. Google Form sebagai Alternatif Pembuatan Latihan Soal Evaluasi. The $6^{\text {th }}$ University Reasearch Colloqium 2017 Universitas Muhammadiyah Magelang.

Nelson, Ricky Sihite. 2015. Peranan Data Dalam Perencanaan dan Evaluasi Pembangunan. https://mataerlang.blogspot.com/2015/10/peranan-data-dalam-perencanaan-dan.html 
Seminar Nasional Penelitian dan Pengabdian kepada Masyarakat

Universitas Sang Bumi Ruwa Jurai Tahun 2020

Peraturan Menteri Dalam Negeri Nomor 12 Tahun 2017 Tentang Pedoman Penyusunan Dan Pendayagunaan Data Profil Desa Dan Kelurahan

Undang-Undang Republik Indonesia Nomor 25 Tahun 2004 Tentang Sistem Perencanan Pembangunan Nasional. 